\title{
SOPRONBÓL ÁTTEKINTVE: MAGYAR MUNKAVÁLLALÁSI TENDENCIÁK AUSZTRIÁBAN
}

OVERVIEW FROM SOPRON: HUNGARIAN EMPLOYMENT TRENDS IN AUSTRIA

\section{Balázs Ferenc}

PhD hallgató

Szent István Egyetem, Gazdaság- és Társadalomtudományi Kar, Enyedi György Regionális Tudományok Doktori Iskola

E-mail: fbalazs2001@yahoo.com

\section{Összefoglalás}

Tanulmányomban azokról a tendenciákról lesz szó, melyek a magyarok ausztriai munkavállalását jellemzik az elmúlt 10-15 évben. Viszonyítási pontom Sopron városa, mely a magyarországi belső migráció egyik legfontosabb céltelepülésévé vált. Az elözmények összefoglalását követően a határ közeli városok szerepváltozásainak áttekintését adom meg, majd az Ausztriát célzó magyar migrációs tendenciák jellegzetességére koncentrálok. Primer kutatási eredményeim tükrében bemutatom, hogy az új és régi soproniak hogyan viszonyulnak a migráció kérdéséhez, milyen jelentéstartalmat társítanak a „soproni” és a „soproniság” kifejezésekhez, valamint, hogy milyen okokat sorakoztatnának fel, ha úgy döntenének, hogy elköltöznek a városból. Összegzésként rávilágítok arra, milyen szerepe van a munkavállalási célú migrációnak a határ melletti térségek térszerkezetének újjászervezésében. Kutatási eredményeim rávilágítottak arra, hogy az átalakuló térszerkezet újszerü közigazgatási szabályozási szemléletet kíván, a politikai döntéshozók figyelmét a nemzeti szintről a regionális szintre, az országok közötti együttmüködésre irányítva.

\begin{abstract}
In my study I will look at trends, which characterize the employment practises of Hungarians in Austria over the last 10-15 years. My reference point is the city of Sopron, which has become one of the most important destinations of internal migration in Hungary. Following the summary of the foregoing, I give an overview of the role changes in the cities near the border, and then focus on the specificity of Hungarian migration trends towards Austria. In the light of my primary research results, I present how new and old inhabitants of Sopron relate to migration question, the meaning they attach to the terms ,Soproni” (the meaning of living in Sopron) and „Sopronism", and the reasons that they would suggest if they moved out of to city. In conclusion, I highlight the role of labour migration in reorganizing the spatial structure of border regions. My research results have highlighted the fact that the changing spatial structure requires a novel approach to administrative regulation, shifting the attention of policy makers from the national to the regional level, with the aim of cooperation between countries.
\end{abstract}

Kulcsszavak: munkavállalási célú migráció, térnyitódás, regionális szint, döntéshozatal, gazdaságszerkezeti átalakulás

JEL besorolás: J61, R10, C83

LCC: HT388 


\section{Bevezetés}

A rendszerváltó országok uniós csatlakozásával a tagországok közötti migráció új lendületet vett, jellege megváltozott a korábbiakhoz képes. Az új típusú vándorlásnak az elsődleges célja a munkavállalás (Lakatos, 2015). Sopron városa a Kelet és Nyugat között húzódó vasfüggöny lebontását követően, Nyugat-Magyarország addig zárt határvárosából, két irányban nyitott településsé vált, bár a munkaerő korlátozástól mentes szabad áramlása a régebbi uniós országok eltérő szabályozásából adódóan, évekkel az új országok csatlakozása után valósult meg. A korábbi zárt térszerkezet társadalmi leképeződése, azaz a társadalom térhasználata megváltozott: a határok menti, megerősödő, két irányban nyitott régiók részben mint célzónák, részben mint közvetítő közegek kezdtek funkcionálni. Magyarország 2004-es uniós csatlakozása, majd néhány évvel ezelőtt az osztrák munkavállalás bürokráciájának egyszerüsítése és a korlátozás feloldása, többek között azt eredményezte, hogy a Lajta folyó keleti oldalának magyar nagyvárosaiban - Sopron, Győr, Mosonmagyaróvár - és a Fertő-tó környékén, megnőtt a lakosság száma. Ez a demográfiai többlet a szabad áramlás terének kibővülésével magyarázható: a korábbi határtelepülések Magyarország egészét tekintve alakultak a szegényebb régiók lakosságainak célvárosaivá. A többlet nem a természetes szaporulatnak, hanem az országon belül zajló migrációnak köszönhető (KSH, 2013). A Magyarország más területeiröl betelepülök jelentős részét vagy a nyugat-magyarországi, vagy az ausztriai, elsősorban burgenlandi munkavállalás lehetősége motiválja, mindamellett, hogy Ausztria legkisebb munkaerőpiaca, 2017-es adatok alapján a 104000 foglalkoztatottjával (Projactive Consulting, 2018). Adott térség körülményeiben és feltételrendszerében bekövetkező változások miatt, egzisztenciális motívumú bevándorlás megy végbe a térségben, annak településeire irányulóan. Ilyen hatás kiváltására lehetnek képesek azok a (kontinentális, államszerkezeti, (dez)integrációs politikai folyamatoknak kitett) regionális átalakulások, melyek egy-egy térség (és települései) szerepének le- vagy felértékelődését hozzák magukkal.

Sopron városban a földrajzi determinizmus és az európai integrációs folyamat teret és utakat engedett a szabad áramlásoknak, a korábbi (ország- és városhatárba zárt) népességet kétirányú mobilitási lehetőségeknek és hatásoknak kitéve.

\section{Térnyitódás - kapuszerep a köztes térben}

Sopron a földrajzi kontaktzónának számító Lajta-vidék keleti szélén, nagyjából a folyó szakaszának felénél helyezkedik el. A folyó természetes képződményként, az Osztrák-Magyar Monarchia idején, Magyarország akkori nyugati határfolyójának szerepét töltötte be (ennek elözményei a XI. század közepére nyúlnak vissza). A térség fontosságát annak az államocskának rövid krónikája is igazolja, melyet a Trianon utáni időszakban magyar katonatisztek csapatai az osztrák hatalom ellenében, Sopronnal a központban, kikiáltottak. Az Örvidék két részre osztott egyik zónájában Sopron városa az ennek a helyzetnek a rendezésére kiírt népszavazás eredményeként kapta meg a „hüség városa” címet (Szabó, 1999).

Az 1949-es aknazár (vasfüggöny) a burgenlandi magyarságot az anyaország területeinek irányából izolálta. A katonai jellegü zárat 1956-re visszabontották, ezért tudtak a forradalom idejében százezres nagyságrendben emigrálni Magyarországról. A napjainkban regisztrálható állapotok gyökereit még a rendszerváltás előtti időszakban kell keresni, a gazdasági kapcsolatok Ausztria és Magyarország között különösen az azt megelőző években erősödtek meg (Fóti, 2003). A határ menti kapcsolatok előmozdítása érdekében már 1985-ben közös osztrák-magyar területrendezési és tervezési bizottság alakult, szükebben a Lajta-vidék, tágabban Nyugat-Magyarország és Burgenland tartományának együttmüködését elősegítő céllal (Nyitrai, 2012). 1988-89-ben rekordméreteket öltött az elsősorban Burgenlandba, a Lajta- 
menti városokba irányuló bevásárló turizmus (Valuch, 2014). A vidék köztes jellegét, valamint azt, hogy a tér karakteréből a közigazgatási vonatkozás miatt nem kerül ki a határjelleg, jól mutatja, hogy az elmúlt évek áthaladó menekülthullámának nagy része Győrből nyugat fele haladt át a térségen. A háborús térségekböl érkező menekültek beáramlását jogi, majd fizikai akadályozó eszközök telepítésével próbálta Magyarország megakadályozni, 2016 nyarán kiegészítve ezt a mélységi határvédelem bevezetésével. Ezek az intézkedések arra irányítják a figyelmet, hogy a térség illetve a kontinens ezen részének átalakulása szakaszokban zajlott le, az elszigeteltségtől a permeabilitáson át addig, hogy a Balkán államai után Magyarország és Ausztria is a globális átjáró részévé vált, melynek végpontjában Németország vagy más nyugati állam területe áll.

A 2001-2011-es, népességre vonatkozó adatok azt mutatják, hogy Györ-Moson-Sopron megye népessége mintegy 8,1-12\%-ban nőtt, különösen Sopron és (jelenlegi) kistérségi településeire és Győrre igaz ez. Lényeges, hogy a megye népessége (és föként a határhoz közeli településeké) ebben az időszakban a bevándorlási nyereségből gyarapodott (Hidas et al., 2012). Ezért az összességében évtizedek óta kedvezötlen demográfiai tendenciák ellenére, ideértve a kivándorlási hullámot is (L. Rédei, 2013), a térség a fővárossal együtt megőrizte népességmegtartó és népességkoncentráló képességét.

Az 1993-as szabad kereskedelmi egyezséget követően jelentős strukturális átrendeződés történt a térségben. A kétpólusú világ felbomlásával újrafogalmazódtak az igények a keleti-nyugati kapcsolatok megerősítésére. Elsőként a bérmunka-alapú termelés lépte át a korábbi külső (nyugati munkavállalás) és belső (munkaerö-beáramlás) határokat, az 1990-es évek második felében megindult a regionális specializáció (feldolgozóipar, kereskedelem, logisztika), nőtt az export érték, és erősödött a hozzáadott értéket hordozó termelés (Rédei et al., 2002). GyőrMoson-Sopron megyét 1991-ben összetartozás, a beáramló tőke lokális munkaerőre támaszkodása, ,a külföldi müködő tőke, a beruházások nagysága, az akkor is még mérsékeltnek tekinthető munkanélküliség, telefonellátottság és a vállalkozások közel azonos jelenléte határozta meg [a fövároshoz képest - a szerzö]" (Rechnitzer, 2001). A köztes tér tehát két irányban vált átjárhatóvá: a korábbi (fizikai és szimbolikus) határoknak megnövekedett a permeabilitása. A zárt határok perifériális területeket szegmentáltak a határ mindkét oldalán (Rechnitzer, 2001), ám a rendszerváltást követően önálló térségként kezdett karakterizálódni a korábbi peremvidék. Köztes jellegét jól mutatja, hogy a menekültek számára még mindig van annak jelentősége, magyar vagy osztrák területen állítják-e meg őket. Tehát a Lajta két partja két irányban nyitott társadalmi és gazdasági vidéket jelent, melynek a folyótól keleti irányba Sopron (mely a Fertőtáj meghatározó magyarországi déli városaként, kistérségi szerepénél fogva, 40 települést és közel 100.000 főnyi lakosságot integrál) gateway településeként szolgál. A korábbi határvidék napjainkban cél- és kontaktzóna: átjárhatósága a jogi szabályozás, az átnyúló társadalmi-gazdasági-kulturális kapcsolatok révén mindkét irányból (illetve akár Szlovákia felől is) folyamatos. „Burgenland és Magyarország határ közeli részei a személyes kapcsolatok, a nyelvi közösség és a helyi kultúra által összefüzött szerves egységnek tekinthetö" (Sik, 1999, 168 p.).

A rendszerváltást követően Sopron, Győr, Mosonmagyaróvár és térségeik határzónából növekvő gazdasági teljesítményt és áruforgalmat kibocsátó várossokká váltak: a korábbi térfelhasználás megváltozott, az ágazati, a kereskedelmi, turisztikai nyitottság mellett társadalomszerkezeti átalakulás is lezajlott, zajlik. Milyen szerkezetei átalakulás figyelhető meg a növekvő gazdasági teljesítményben? A feldolgozóipari átmenetböl az integrálódás ebben a térségben is a földrajzilag közelebb lévő nagyobb piac irányába mutat, megerősítve a Győrre koncentráló autóipari beszállítókat, a logisztikai iparágat, valamint az egészségügyi, turisztikai, pénzügyi szolgáltatást nyújtókat. Mosonmagyaróvár a Lajta-vidék iparilag egyik legfontosabb 
városa: a legtöbb nagyüzem a rendszerváltozás után is tovább müködött, de több termékfeldolgozó és -előállító társaság is megjelent a településen (mezőgazdasági termékek feldolgozása, építőanyag-gyártás, valamint a győri autógyártás egyes beszállítói). A város a Győr-Bécs-Sopron korridoron fekszik. Az északi közlekedési folyosó a Lajta-vidék keleti zárásán, Mosonmagyaróváron át halad Győr felé, nyugati irányba pedig Bécs jelenti a tengely másik végét. Kontinentális viszonylatban az északi folyosó annak a nagy közúti tengelynek része, mely a német területeket köti össze a Balkán országaival (a Phare-fejlesztéseknek is kiemelt célja volt a határmenti kontaktzónák integratív fejlesztése). A térségben a 2010-es adatok tanulsága szerint Nezsider (Neusiedl am See), Kismarton (Eisenstadt) és Ruszt (Rust) városok lakossága növekedett (Nyitrai 2012,7). A jövedelmi viszonyok között jelentős eltérés mutatkozik: Burgenlandban tartományi szinten 2007 és 2009 között 2,5\%-kal nőtt a GDP, az egy före jutó jövedelem pedig 1,5-2,5-szerese a nyugat-magyarországi adatoknak (Nyitrai, 2012).

A népességi, kereskedelmi mozgások, a gazdasági jellegü szolgáltatások igénybe vétele mind Magyarország, mind Ausztria irányából kétirányú, lépcsőzetesen egymásra épülő mobilitási tapasztalásokat magával hozott, növelve a térség alkalmazkodási képességét. Győr és Sopron helyzetének értékelését, regionális szerepkörének megrajzolását a városok térbeli hatásait feltáró kutatások alapozzák meg (Rechnitzer, 2014). Győr erős gazdasági (autógyártás és annak beszállítói oldala) és logisztikai regionális központtá, a Bécs-Pozsony-Budapest fejlődési övezet regionális centrumává alakul (Rechnitzer, 2014), Sopron elsősorban a vezető oktatók illetve a kultúra, művelődés terén tudott vele konkurálni.

Sopron két ipari parkja ellenére sem prognosztizálható iparvárossá fejlődése, a tőke és a munkaerő vonzásában is versenyeznie kell a vidék (és a régió) nagyvárosaival, ideértve az „átellenes” osztrák városokat is (Deák, 2015). Fejlődési irányként a termeléshez csatlakozó üzleti szolgáltatások nyújtása lehet a megalapozó kategória. Ennek köszönhető, hogy nem mondható magasnak a szakmunkát végzők aránya, ezen túlmenően e munkavállalók egy része nem is helyben vagy a környéken, hanem más területen vagy Ausztriában vállal munkát. A magasabb kereset mellett a munkakultúra-szervezés is vonzó, illetve a mobilitás későbbi lehetséges fázisában a szociális jelleg felerősödése (család-áttelepülés, a gyermek jövőjének tervezése). Nem meglepő, hogy a beszélt idegen nyelvek közül a német áll az élen. Sopron városának helyzetét, Ausztriával való kapcsolatát, gateway-szerepe és erős humánbázisa (Rechnitzer et al., 2014) jelenleg nagyobb mértékben határozza meg mint potenciális iparosítási lehetőségei.

\section{Magyarok Ausztriában: munkavállalási tendenciák}

A magyar munkavállalók Ausztria iránti érdeklődésének jele, hogy 2005, valamint a 2008-as schengeni nyitás után ugrásszerüen megnőtt. Emelkedni kezdett a kinyíló határvárosokba ingázó, valamint az osztrák területen munkát vállalók száma, amely csoportok között mind nagyobb arányt képviseltek az ország keleti területeiről áttelepülők. Az ország a második helyen állt a 2011-es adatok szerint Németország mögött a magyarok munkavállalási célú országainak listáján (Hárs, 2011). A 2015-ös adatok szerint ${ }^{1}$, a legtöbb uniós külföldi Bécsben él. Bécsi székhellyel 49 német, 18 magyar és 14 olasz vállalkozást alapítottak tavaly. A 2005 és 2015-ös adatok összevetéséből kiderül, hogy 10 év alatt duplájára nőtt az Ausztriában élő uniós tagállamból érkező külföldiek száma. 2005-ben a szerbek, törökök, bosnyákok érkeztek

\footnotetext{
${ }^{1}$ Az itt következő adatok - további külön jelzés nélkül - az alábbi, migrációs tendenciákkal foglalkozó portálról származnak: $\quad$ http://medienservicestelle.at/migration_bewegt/2016/05/09/eu-migration-nach-oesterreichentwicklungen-und-trends/
} 
a legtöbben, de jelen voltak más balkáni és közép-európai országból is bevándorlók. 2015-ben a legtöbb, Ausztriában élö külföldi állampolgár (176 ezer fö) német volt. A regionális és települési eloszlásban a magyarok számára talán legfontosabb céltérség, Burgenland áll az utolsó helyen az ott élö külföldiek számát tekintve, annak ellenére, hogy az elmúlt 10 évben itt volt a legmagasabb (137\%) a növekedés.

A kint élő magyarok 2005-ben nagyjából 15 ezren voltak, 2015-ben viszont már 63.600-an, ami több mint 5\%-os arány, nagyjából Sopron és közvetlen vonzáskörzetének lakosságszámával megegyező tömeg. Ebben az adatban - természetesen - nem jelennek meg az ingázók vagy idénymunkások (különösen a burgenlandi háztáji mezőgazdasági termelésben van nagy szerepük), akik helyi kötődéseiket gyakran családon belül is tovább örökítik, így több évtizedes előnyük van más munkavállalókkal szemben az osztrák gazdáknál, bortermelőknél (Sik, 1999). Idén januárban közel százezer (98 227) magyar állampolgár dolgozott Ausztriában (HRportál, 2019)

Mind a magyar, mind az osztrák statisztikákban visszatérő adat, miszerint Ausztriában elsősorban építőipari szakmunkásokat, szakképzett vendéglátó ipari munkaerőt, bolti eladókat, ápolónőket várnak Magyarországról, tehát az ilyen típusú munkára érkezők lesznek az új lakosok és az ingázók. A mezőgazdasági idénymunkák egy részét meglévő kapcsolatrendszeren keresztül (Gödri, 2010), nem hivatalosan látják el magyar és más külföldi munkavállalók (2005-ös, becsült adatok szerint, nagyjából 10 ezer fő járt át a határon be nem jelentett idénymunkát végezni az osztrák földeken, lásd. Hardi, 2005). A frisebb kimutatások szerint Burgenlandban minden hetedik munkavállaló magyar. Továbbra is elsősorban az élelmiszeripari és a vendéglátási területeken helyezkednek el a magyarok, de a szellemi munkát végzők aránya is számottevően megnőtt például az egészségügyben (253 szakorvos, 152 fogorvos, 83 háziorvos) (Határátkelő, 2019).

A munkaerő-migráció résztvevői jellemzően a legszegényebb társadalmak leghátrányosabb helyzetü csoportjaiból kerülnek ki (Portes-Sensenbrenner, 2001). Az Ausztriában munkát vállaló magyarokra igaz az is, hogy tagjaik főként a fiatalabb korosztályokból kerülnek ki ezzel a nemzetközi migráns tendenciák (értve ezalatt az önkéntes, életminőség-javító célú térváltoztatást) általános trendjéhez illeszkednek (Kincses, 2014). A munkavállalási célú migráció hazai és nemzetközi tendenciáinak elemzését és a fogalom meghatározását a szakirodalom szerint nagymértékben befolyásolja, hogy milyen adatsorokat vizsgálunk, de általános jellemző, hogy az egyén valamilyen gazdasági szemléletű megfontolást tesz, és a várható haszon (munka, magasabb bér) reményében dönt mellette (Lakatos, 2015; Hárs-Simon, 2015).

Ugyanakkor ezt a kitételt egyes iskolázottsági adatok árnyalják: a szegényebb, alacsonyabb társadalmi státuszú rétegek közül is elsősorban a határrégióban jól hasznosítható szakmával rendelkezők képezik a magyar munkaerö-migránsok „derékhadát”, a Sopronba települőket majd onnan ausztriai munkát vállalókat. Érvényesül az általános szabály: alacsonyabb iskolai végzettségüek nagyobb arányban vesznek részt kisebb távolságú migrációban, nagyobb távolságok esetén a felsőfokú végzettségek dominálnak (Kincses, 2015). A migráció nemzetközi tendenciáira jellemző, hogy az abban résztvevők elsősorban a 20-40 éves (Hárs, 2011) korosztály (L. Rédei, 2014) közül kerülnek ki, ez a kitétel a Sopronba majd a Sopronból Burgenlandba irányuló migráció esetében is igaz, noha a mobilitási életkor-mező egyértelműen szélesedik. Figyelemreméltó, hogy a Lajta osztrák oldalán még a gazdasági válság éveiben is évi átlagban 8.000 magyar vállalt munkát (Nyitrai, 2012). Osztrák oldalról érkezve magyar területen lényegesen kevesebb munkavállalóról lehet beszélni. A térségben a vidék nyugati 
szegmensében a 15-64 éves népesség 73,7\%-a aktívnak számít a munkaerőpiacon (2011-es burgenlandi adat, lásd. Nyitrai, 2012), ez az arány Magyarországon közel 10\%-kal elmarad.

Megemlítendő, hogy a Burgenland tartományban munkába álló, akár a napi-heti ingázását is vállaló magyarok száma még a 2011. májusáig érvényben lévő adminisztratív korlátozás ellenére is nőtt. A már említett, részben a földrajzi adottságnak, részben pedig a sürü településés úthálózatnak köszönhető kétirányú nyitottság különösen kedvező volt a munkavállalói célú mobilitás számára.

„A mobilitás hálózatait az ún. földrajzi determinizmus határozza meg. Az országok közötti közlekedés csatornáit, amelyek a migráció ellenőrzési pontjai is, természetföldrajzi és infrastrukturális (repülőterek és határátkelök) tényezők függvényei. A schengeni határokon belül a korábbi határok elválasztó szerepe szünt meg, így váltak az egykori országhatárok menti térségek ma belső határként aktív kontaktzónává a gazdaság, a munkaerő és a kereskedelem, ingatlanforgalom területén.” (L. Rédei, 2014, 40 p.)

Sopron városa bizonyult az ausztriai irányú munkavállalás tekintetében az egyik legfontosabb gyüjtőpontnak, „kapuvárosnak”, mely a déli és középső Lajta-vidék, de akár Bécsújhely és Bécs irányába is ki tudja bocsátani a munkavállalókat. A legfontosabb motivációt a jobb kereseti lehetőség jelenti: Burgenlandban tartományi szinten 2007 és 2009 között 2,5\%-kal nőtt a GDP, az egy före jutó jövedelem pedig 1,5-2,5-szerese a nyugat-magyarországi adatoknak. Ezek a különbségek kistérségi szinten, illetve értelemszerủen a kontaktzónát képezö Lajta folyó magyar és osztrák oldalán is megmutatkoznak (Nyitrai, 2012).

A Lajta burgenlandi oldalán a sürü kistelepülési hálózat mezőgazdasági tevékenységnek ad otthont. A mezőgazdasági területek döntő nagysága szántó. A legjelentősebb a kalászosok és a kukorica szántóföldi termesztése, de az utóbbi években növekvőben van az olajos magvak termesztésének aránya. Ezekben a mezőgazdasági munkákban jut szerep a magyar idénymunkásoknak. Az igen kedvező agroökológiai feltételek ellenére, a vidéken visszaszorulóban van a konyhakerti gyümölcstermesztés, ahogy néhány, alapvetőnek mondható haszonállat-faj kivételével a haszonállat tartás is (Nyitrai, 2012). A csökkenő mezőgazdasági termelést jelző tendencia alól a magas színvonalú tejtermelés jelent kivételt: a burgenlandi tejfogyasztási adatok meghaladták az ausztriai átlagot (ezt közelítették meg a Győr-MosonSopron megyét jellemző értékek). A vidéken fontos a turizmussal összefüggő bortermelés, melyet jellemzően családi pincészetekben folytatnak.

A Lajta burgenlandi folyószakaszhoz közelebb fekvő kistelepülési háló, mezőgazdasági meghatározottságot mutat, a távolabbi illetve glokális viszonylatban meghatározó települések némelyike viszont fontos vállalkozásfejlesztési és technológiai központtal rendelkezik (Kismarton, Nezsider). A Lajta környékének osztrák oldala (és különösen Dél-Burgenland) valójában szerény ipari kibocsátással rendelkezik, nehézipari termelés helyett elsősorban a kisebb vállalkozások fejlődését szolgáló környezetet kínál. Ezzel egy fontos nemzetközi trend realizálódott osztrák oldalon: „A 20. század végére összekapcsolódtak a tudásteremtés lokális helyszínei és a tudásfelhasználás globális terei." (L. Rédei, 2014, 39 p.). Ennek az összekapcsolódásnak éppúgy jele a néhány ezek magyar diák ausztriai iskolába, illetve óvodába járást segítő iskolabuszok, mint a határmenti vegyesvállalatok és a kapcsolódó tudástranszfer. Ennek az alkalmazkodó-képességnek köszönhető, hogy a más területekhez képest a Lajta osztrák oldala (és Burgenland tartománya) könnyebben vészelte át a gazdasági válságot és tudta ezekben az években is fogadni a magyar munkaerőt. Ennek egyrészt a kisebb vállalkozások megerősítése, másrészt a vegyes és tudástőkére épülő gazdaságszerkezet extrapolálása volt a kulcsa. 
„A fejlődést, a vállalkozások változó körülményekhez való könnyebb alkalmazkodását itt a technológiai központok létrehozása is segítette. [...] Ezek alapján súlyponti területnek tekintik az elektronikaipar, az információ- és kommunikáció-technológia, a megújuló energiák hasznosítását, a vidék népességmegtartó-képességét is erősítő turisztikai lehetőségek kiaknázását, valamint a mezőgazdaság fejlesztését." (Nyitrai, 2012, 13 p.)

A Lajta két oldalának ipari szerkezetében jól látható a különbség, „Az ipari termelés szerkezete eltérő a határ két oldalán, a kibocsátás gazdasági ágak szerinti összetétele ugyanakkor mind a két területi egységben hasonlít a saját országaikéhoz." (Nyitrai, 2012, 18 p.) Az osztrák oldal összképe ezért némileg homogénebb képet mutat, kevésbé dominálják a térség rurális, kistelepülési részeit nagyvárosok (míg a magyar oldalon Mosonmagyaróvár és Sopron integráló szerepe meghatározó).

Milyen helyzetben van az a soproni vagy Sopronba települö, aki német nyelvtudás birtokában vállalna ausztriai munkát? A soproni korosztályi aggregált adatok szerint, 30.959 főből 20.351 fő beszél valamilyen idegen nyelven; ebből 19.773 fő a németet jelölte meg, a többi adat ismeretében ezres nagyságrendre tehető azok száma, akik a német mellett még egy másik idegennyelvet is beszélnek. Ez nem meglepő: Sopron és térségének valamint regionális viszonylatának közlekedéshálózata, kereskedelme mind magyar, mind osztrák területen fejlettnek mondható. „Különösen a határ menti területek azok, ahol a vállalkozások az ellátási típusú kapcsolataikat munkaerő növelése nélkül képesek bővíteni. A közlekedési csomópontok, illetve az e-gazdaság számára kedvező adózási pontok önmagukban növekedési pólusokat generálnak." (Rédei et al., 2002, 90 p.). Ugyanakkor a magyar munkavállalók nyelvtudása - a korábban hivatkozott 2005/2015-ös adatok összehasonlítása szerint - arányaiban elmarad más kelet- és közép-európai (lengyel, horvát, román, bolgár), Ausztriát megcélzó munkavállalók nyelvtudásától, akik 2014-től szintén szabadon vállalhatnak munkát az országban. Csekély nyelvtudással a magyar munkavállalók földrajzi determinációból és a nyitott regionalitásból eredő helyzeti előnye is veszélybe kerülhet.

A magyarok németországi és ausztriai munkavállalási karaktere eltérő, előbbi ország esetében a magyar migrációra a rezidensség, utóbbinál a cirkularitás jellemző. 2010-ben közel háromszor annyi magyar férfi vállalt munkát Ausztriában mint nő (Hárs, 2011), ugyanezen évből származó adatok szerint a migrálók mintegy 47\%-át a legfeljebb szakmunkás képesítéssel rendelkezök tették ki. A kutatási adatok szerint ugyanakkor ezzel a szakmunkások felülreprezentáltak a migránsok között, mivel otthoni arányuk nagyjából 30\%-ra tehető. Ez megegyezik a Sopron kapcsán korábban jelzettekkel: szakképzett munkaerő viszonylag kisebb arányban van jelen a város és térségének munkaerő-piacán, mivel számos munkavállaló osztrák területen vállal munkát.

Az ausztriai magyar munkavállalók bázisát tehát két fö csoport képezi. Az egyik, egyre növekvő létszámú csoportot a Győr-Moson-Sopron és Vas megyékbe az ország más térségeiből beáramló munkavállalók jelentik, akik belső migrációs nyomás alá helyezik Sopront és a határ melletti városokat (emlékezzünk vissza, hogy nagyjából több ezer fö, azaz Sopron lakosságának 10-15\%-a belső migránsként járult hozzá a település lakosságának növekedéséhez a 2011-es népszámlálási adatok szerint). A másik csoportot az Ausztriával szomszédos említett két megye helyi lakossága adja, akik között jelentősen nagyobb az ingázók aránya: 2013-as adatok szerint (Lakatos, 2015) a teljes ausztriai magyar munkavállalókból több mint 21 ezren a két megyében éltek. A határ mellett élök betelepülökhöz képest alacsonyabb tranzakciós költségei és lokális kötődéseik preferáltabbá teszik körükben az ingázás vállalását. 
Akár a belső migrációból duzzadó, Sopront (és más határ melletti településeket) bázisnak használó, Ausztriában munkát vállaló csoportot, akár a helyi, elsősorban ingázásban érdekelt réteget tekintjük, a magyar munkavállalók ausztriai munkavállalása ismét a határrégió reintegrálódására irányítja figyelmünket. „Egy közepes városnyi ember szerzett már ennek révén tapasztalatot a határ másik oldalán élőkről, s arról a világról [...] A határ munkaügyi elválasztó szerepének csökkenésével azt várhatjuk, hogy ez a szféra egyre inkább egységes lesz, s kialakul az az átmeneti zóna a határ mentén, amely a Kárpát-medencének ezt a táját mindig is jellemezte." (Hardi, 2005, 81 p.).

\section{Anyag és módszertan}

A felmérésben 60 fö vett részt, 43,3\%-uk (26 fö) új soproni és 56,7\%-uk (34 fö) régi soproni. Jelenlegi lakhelyükön 1-50 éve laknak $(\mathrm{M}=14.92, \mathrm{SD}=13.82)$. Több, mint felük 1-10 éve él ott (52,5\%, 31 fö), 32,2\%-uk (19 fö) 11-30 éve és további 9 fő (15,3\%) 31-50 éve. A későbbi elemzések során az új és régi soproni csoportok közötti különbségeket vizsgáltam. A vártnak megfelelően a régi soproniak szignifikánsan több éve laknak $(\mathrm{M}=19.24, \mathrm{SD}=15.20)$ jelenlegi lakhelyükön, mint az új soproniak $(\mathrm{M}=9.43, \mathrm{SD}=9.54)(\mathrm{t}(57)=-3.030, \mathrm{p}=0.004)$.

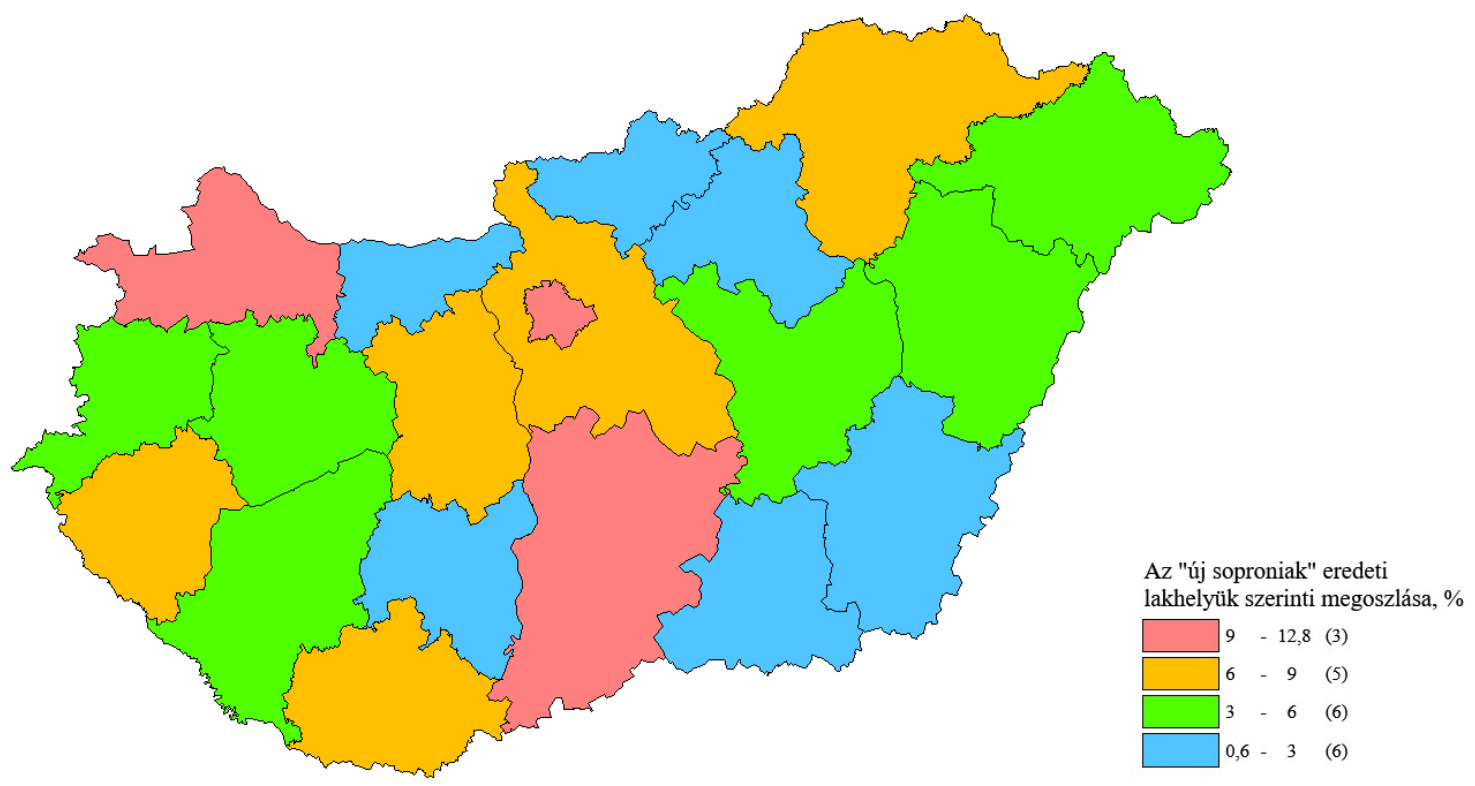

\section{1. Ábra: Az „Új soproniak” származási hely szerinti megoszlása}

Forrás: Saját kutatás, 2017.

Leíró statisztikai mutatóként skálaváltozók esetében az átlag és szórás adatokat, kategóriaváltozóknál a gyakorisági adatokat (\% és fö) tüntettem fel. Két csoport különbségének vizsgálatát skálaváltozó mentén független mintás t-teszttel végeztem, amennyiben a szóráshomogenitás feltétele nem teljesült a Welch-féle d-próba eredményei alapján következtettem. Két nominális és/vagy ordinális változó függetlenségét kereszttáblaelemzéssel végeztem. 2x2-es kereszttábláknál Fisher-féle egzakt próbát, 2x2-esnél nagyobb kereszttábláknál Pearson-féle khi-négyzet statisztikát alkalmaztam. Amennyiben a kereszttábla-elemzés alkalmazási feltételei (minden kategória várható gyakorisága legalább 1 , és a kategóriák nem több mint 20\%-ban a várható gyakoriság nem kevesebb, mint 5) nem teljesültek, a gyakorisági adatokat vizsgáltam. A statisztikai elemzések során a rögzített 
szignifikancia szint $\mathrm{p}=0.05$ volt. A statisztikai elemzéseket IBM SPSS 20 statisztikai programmal végeztem (IBM SPSS Statistics, IBM Corporation, Chicago, IL).

\section{Eredmények}

\section{Lakóhely és munkahelyváltás}

Elsőként a lakóhely-váltás és munkahelyváltás közti kapcsolatot, a lakóhely és munkahely változtatásának szándékát vizsgáltam a teljes mintán, illetve az új és régi soproniak körében. Továbbá a családtagok közelségét és ennek fontosságát a megkérdezett személyek körében. A résztvevők többségének legutóbbi lakóhely-váltása független jelenlegi munkahelyétől $(80,4 \%$, 45 fó), 11-en jelezték (19,6\%), hogy a jelenlegi munkavégzés helye az egyik oka a korábbi lakóhelyváltásnak. Az új soproniak esetében közel fele-fele arányban tapasztalható ez, 44\%-uk (11 fö) munkahely miatt váltott lakóhelyet, a régi soproniak körében egyetlen személy sem adott igen választ erre a kérdésre. A jelenlegi lakóhely változtatását 2-3 éven belül 20\%-uk tervezi (12 fó) és további 6 fö (10\%) bizonytalan ebben a kérdésben. Munkahelyváltást 2-3 éven belül 28,3\%-uk (17 fö) tervez, további 4 fö bizonytalan. A lakóhely $(\chi 2(1)=0.193, p=$ $0.661)$ és/vagy munkahelyváltást $(\chi 2(1)=0.001, \mathrm{p}=0.992)$ az új és régi soproniak közel azonos aránya tervezi 2-3 éven belül. Lakóhelyét az új soproniak 25\%-a, a régi soproniak $20 \%$-a tervezi megváltoztatni, munkahelyet az új soproniak 30,4\%-a, a régi soproniak 30,3\%-a váltana. Többségük (58,3\%) esetében sok családtagjuk él a közelben és 48,3\%-uknak fontos is, hogy közel legyenek tágabb családjukhoz. A régi soproniak nagyobb arányára jellemző $(\chi 2(1)=$ 14.343, p < 0.001), hogy sok családtagjuk él a közelben $(79,4 \%)$, mint az új soproniakra (30,8\%). Ugyanakkor mindkét csoport számára egyaránt fontos, hogy a közelséget fenntartsák tágabb családjukkal $(\chi 2(1)=2.419, \mathrm{p}=0.120)$. A régi soproniak $60,6 \%$-a, az új soproniak $40 \%$ a jelezte ezt.

\section{A migráció jelentése és a migráció jelensége}

A migráció esetében egyrészt a migráció kifejezés jelentését vizsgáltam és azt, hogy a személyek véleménye szerint mikor találkoztak először migrációval életükben és mit gondolnak a belső migrációról. Ezt követően több oldalról igyekeztem feltárni a migránsokkal kapcsolatos véleményeket és attitüdöket, mint a híradásokban megjelenő migránsok, illetve a betelepülők megítélése és támogatása, valamint az országon kívülről és belülről érkezők elfogadása. A migráció kifejezés esetében a megkérdezett személyek többsége egyértelmủen a külföldiek bevándorlására és letelepedésére gondol (43,3\%, 26 fö), viszonylag gyakori válasz volt még a lakhelyváltoztatás és a belső migráció (13\%, 8 fö). Érdemes megjegyezni, hogy a válaszok nagyfokú heterogenitása volt jellemző. A három leggyakoribb válasz közül a külföldiek bevándorlása és letelepedése volt statisztikailag is vizsgálható az új és régi soproniak körében. Ebben az esetben a válaszadók aránya az új és régi soproniak körében szignifikáns mértékben nem különbözött $\left(\chi^{2}(1)=0.443,0.602\right)$. Érdemes megjegyezni, hogy a belső migrációt az új soproniak 7,7\%-a adta, a régi soproniak 17,6\%-a, valamint a belső migráció választ adók mindegyike az új soproniak csoportjába tartozott (1. táblázat). Összességében azt tapasztalható, hogy a régi soproniak több negatív tartalmú véleményt fogalmaztak meg a migráció kifejezésével kapcsolatban az új soproniakhoz képest. 


\section{1. táblázat: „Mire gondol Ön akkor, amikor a migráció kifejezést hallja?” kérdésre adott válaszok előfordulási gyakorisága az új és régi soproniak körében (\%)}

\begin{tabular}{|l|r|r|}
\hline \multicolumn{1}{|c|}{ Megnevezés } & Új soproni & Régi soproni \\
\hline külföldiek bevándorlása, letelepedése & 38,5 & 47,1 \\
\hline lakhelyváltoztatás & 30,8 & - \\
\hline belső migráció & 7,7 & 17 \\
\hline elvándorlás, lakhely elhagyása & - & 11,8 \\
\hline politikai helyzet & 3,8 & 8,8 \\
\hline erőszak, háború & 11,5 & - \\
\hline kényszerből & 7,7 & 2,9 \\
\hline keletröl nyugatra vándorlás & - & 8,8 \\
\hline Sopronba bevándorlók & 7,7 & - \\
\hline Közel-Keleti & 3,8 & - \\
\hline iszlám bevándorló & 3,8 & - \\
\hline más emberek & 3,8 & \\
\hline szíriai menekültek & - & 2,9 \\
\hline pénzéhes emberek & - & 2,9 \\
\hline eltérő kultúra, értékrend keveredése & - & 2,9 \\
\hline idegen eredetű főnév & - & 2,9 \\
\hline politika félreértelmezi & - & 2,9 \\
\hline aggodalom & - & 2,9 \\
\hline önszántukból & - & 2,9 \\
\hline
\end{tabular}

Forrás: Saját kutatás, 2017.

A migráció jelenségével többségük 15-20 éve (30\%, 18 fö), valamint 2 éve (31,7\%, 19 fö) találkozott először, ami arra utal, hogy vagy már régóta a köztudatban él a migráció jelensége, vagy az elmúlt évek menekült helyzetével került be az emberek életébe. Ennek megítélése a két vizsgált csoportban jelentős eltérést nem mutatott. Az új soproniak 30,8\%-a (8 fó) adta meg a fenti két választ erre a kérdésre, a régi soproniak 29,4\%-a (10 fó), illetve 32,4\%-a (11 fö). Összességében a megkérdezett személyek további 8,3\%-a (5 fö) jelezte, hogy 7-8 éve, illetve idén/pár éve találkozott először a migráció jelenségével. További 6,7\%-uk (4 fö) 5-6 éve, valamint „évek óta a munkalehetőség miatt”, végül 2 fö 3-4 éve választ adott.

\section{A belsö migráció megítélése}

Az országon belüli lakhelyváltoztatást a jobb munkalehetőség reményében a megkérdezett személyek 45\%-a (27 fö) nem tekinti migrációnak, 53,3\%-uk (32 fó) igen, 1 fö adott talán, bizonytalan választ. Az országon belüli lakhelyváltoztatást migrációnak tekintők és nem tekintők aránya az új és régi soproniak körében statisztikailag szignifikáns különbséget nem mutatott $\left(\chi^{2}(1)=1.224, p=0.303\right)$. Bár a két csoport jelentős eltérést nem mutatott, ugyanakkor fontos megjegyezni, hogy a régi soproniak viszonylag nagyobb aránya $(60,6 \%, 20$ fó)) tekintette ezt a lakhelyváltoztatást is migrációnak az új soproniakhoz képest (46,2\%, 12 fö). A megkérdezett személyek véleménye arról, hogy egyesek országon belül áttelepülnek a jobb munkalehetőségek reményében oda, ahol igény van a munkaerejükre, azt mutatja, hogy összességében a személyek többsége megérti és elfogadja ezt (75\%, 45 fö), „csak” 3 személy adott egyértelmü nem választ erre a kérdésre (a további 12 fö válasza nem volt értelmezhető, mert nem a kérdésre válaszoltak). A régi soproniak 79,4\%-a (27 fö) jelezte, hogy megérti és 
támogatja, az új soproniaknál ennek aránya 69,2\% (18 fó) volt. A nem támogatók aránya az régi soproniak körében 5,9\% (2 fö) volt, az új soproniak közül 1 fő adott ilyen választ.

\section{A migránsok megítélése}

\section{Találkozott-e már migránssal?}

A megkérdezett személyek döntő többsége (80\%, 48 fö) már találkozott Sopronban migránsokkal. További 11 fö (18,3\%) jelezte, hogy még nem és 1 fö nem tudja, bizonytalan választ adott. A régi és új soproniak ebben a kérdésben statisztikailag szignifikáns különbséget nem mutattak $\left(\chi^{2}(1)=2.101, p=0.147\right)$. A vártnak megfelelően, azoknak, akik régebb óta laknak Sopronban, viszonylag nagyobb aránya jelezte, hogy már találkozott migránsokkal (87,9\%, 29 fó), az új soproniakhoz képest (73,1\%, 19 fö).

\section{A híradásokban megjelenő migránsok}

A híradásokban megjelenő migránsok a résztvevők jelentős többsége szerint $(80,8 \%, 42$ fö) migránsnak tekinthetők. További 5 fö jelezte $(9,6 \%)$, hogy csak abban az esetben, ha nem országon belülről érkezik és 1 fö szerint a híradásokban szereplők nem tekinthetők migránsoknak. Érdekes, hogy „csak” 4 fö (7,7\%) jelezte, hogy nem akarja/nem tudja ezt megítélni a híradások alapján. A fentiek alapján is látható, hogy a híradásokban megjelenő migránsok megítélését statisztikailag nem lehetett a két csoport esetében megvizsgálni. Érdemes azonban megjegyezni, hogy az új soproniak csoportjában 1 bizonytalan személy kivételével mindenki a híradásokban megjelenő migránsokat migránsnak tekintette.

\section{Az osztrák állampolgárok megítélése}

A híradásokban megjelenő migránsok megítélése mellett vizsgáltam a személyek véleményét azon osztrák állampolgárokkal szemben is, akik Magyarországon vállalnak munkát. A magyarországi munkát vállaló osztrák állampolgárokat a megkérdezett személyek több mint fele (57,1\%, 32 fö) nem tekintette migránsnak, 19,6\%-uk (11 fö) azonban igen. További 10 személy $(17,9 \%)$ bizonytalan volt ebben a kérdésben, igen is-nem is választ adott, valamint hárman jelezték, hogy nem tudják ezt megválaszolni. Az új és régi soproniak körében az osztrák állampolgárok megítélése jelentős különbséget nem mutatott, a régi soproniak körében viszonylag nagyobb volt azok aránya, akik az osztrák állampolgárokat is migránsnak tekintették, de az eltérés nem volt jelentős (2. táblázat).

\section{2. táblázat: Magyarországon munkát vállaló osztrák állampolgárok migránsként való} megítélése az új és régi soproniak körében (\%)

\begin{tabular}{|l|r|r|}
\hline \multicolumn{1}{|c|}{ Megnevezés } & Új soproni & Régi soproni \\
\hline igen & 13,6 & 23,5 \\
\hline nem & 59,1 & 55,9 \\
\hline igen is, nem is & 27,3 & 11,8 \\
\hline nem tudja & - & 8,8 \\
\hline
\end{tabular}

Forrás: Saját kutatás, 2017. 


\section{A betelepülök megitélése}

Ezt követően az vizsgáltam, hogy mi a személyek véleménye arról, ha országon kívülről települnek be mások Sopronba a jobb munkalehetőségek reményében. Eredményeim alapján a felmérésben résztvevők döntő többsége $(87,9 \%, 51$ fö) megérti és támogatja a betelepülést Sopronba, ha ennek oka a jobb munka lehetősége. Csupán 5 fő jelezte, hogy egyértelműen nem támogatja és ketten adtak igen is-nem is választ. Bár statisztikailag, a minta homogén válasza miatt, ezt a kérdést a két csoport között nem tudtam megvizsgálni, azt tapasztaltam, hogy a régi soproniak alapvetően befogadóbb attitüddel jellemezhetők, a személyek mindegyike megérti és támogatja választ adott erre a kérdésre. Az új soproniak körében ennek aránya 70,8\% (17 fó) volt és a fentieknek megfelelően az elutasítók és bizonytalanok is ebben a csoportban voltak.

\section{A betelepülők támogatása}

A betelepülés elfogadása mellett a betelepülők támogatásával kapcsolatos véleményeket is vizsgáltam, a „Kapjanak-e valamilyen támogatást a betelepülők?” kérdésre adott válaszokkal. Eredményeim azt mutatják, hogy összességében bár nem utasítják el azokat a betelepülőket, akik a jobb munkalehetőség reményében érkeznek hazánkba, vagy Sopronba, mégis támogatást döntő többségük $(71,7 \%, 43$ fö) csak a külföldi menekülteknek adna, illetve 15\%-uk (9 fö) jelezte, hogy nem ért egyet azzal, hogy a betelepülők bármilyen támogatást kapjanak. Csak 4en adtak igen választ, és további 4 személy igen is-nem is, vagy nem tudja választ adott. Ebben az esetben is a minta viszonylag homogén válasza miatt statisztikai összehasonlítást nem tudtam végezni. Amit a gyakorisági adatok alapján érdemes kiemelni, hogy a 4 igen választ adók közül, tehát azok közül, akik egyetértenek azzal, hogy a betelepülők valamilyen támogatást kapjanak, 3-an az új soproniak csoportjába tartoztak (3. táblázat).

\section{3. táblázat: A betelepülők támogatásának megítélése az új és régi soproniak körében (\%)}

\begin{tabular}{|l|r|r|}
\hline \multicolumn{1}{|c|}{ Megnevezés } & Új soproni & Régi soproni \\
\hline igen & 11,5 & 2,9 \\
\hline nem & 15,4 & 14,7 \\
\hline ha külföldi menekült & 61,5 & 79,4 \\
\hline igen is, nem is & 3,8 & 2,9 \\
\hline nem tudja & 7,7 & - \\
\hline
\end{tabular}

Forrás: Saját kutatás, 2017.

\section{Az országon belülröl és országon kívülről érkezök elfogadása}

Végül azt vizsgáltam, hogy a személyek elfogadnák-e az országon belülről, illetve kívülről érkezőket, ha az utcájába vagy a szomszédjába költöznének, valamint milyen okokkal magyarázzák véleményüket. Az országon belülröl érkezők esetében többségük elfogadja (43,1\%, 25 fö), vagy elfogadja, de feltételekhez köti (41,4\%, 24 fö). A kényszerböl elfogadók aránya $10,3 \%$ volt ( 6 fö), valamint csak hárman adtak egyértelmüen nem választ erre a kérdésre. Az országon kívülről érkezők esetében is többségük elfogadást $(35,7 \%, 20$ fö), vagy feltételekhez között elfogadást $(58,9 \%, 33$ fö) fejezett ki. Szintén csak hárman adtak egyértelmüen elutasító választ és egyetlen olyan személy sem volt, aki a „kényszerből elfogadja" választ adta volna. Érdemes megjegyezni, hogy a felmérésben szereplő régi és új soproni személyeket összességében elfogadó attitüd jellemzi a betelepülőkkel kapcsolatban. Ezt alátámasztja az is, hogy viszonylag nagy volt azon személyek aránya, akik mind az 
országon belülről, mind az országon kívülröl érkezőket elfogadnák utcájukba vagy szomszédjukba, ennek aránya $29,1 \%$ volt, tovább azok aránya, akik elfogadják, de bizonyos feltételekkel szintén nagynak tekinthető $(36,4 \%)$. E két válasz keresztmetszetében összességében a megkérdezett személyek $88,7 \%$ volt jellemezhető elfogadó attitüddel. Csupán két olyan személy volt, aki mind az országon belülről és mind az országon kívülről érkezőket „elutasítaná”. Az országon belülről, illetve kívülről érkezőkkel szembeni jellemzően inkább „elfogadó" attitüd miatt az új és régi soproniak statisztikai összehasonlítása nem volt megvalósítható.

\section{4. táblázat: Az országon belülről és kívülről érkezők elfogadása az új és régi soproniak körében (\%)}

\begin{tabular}{|l|r|r|}
\hline \multicolumn{1}{|c|}{ Megnevezés } & Új soproni & Régi soproni \\
\hline országon belülröl érkezök & 38,5 & 43,8 \\
\hline igen, de feltételekhez köti & 3,8 & 15,6 \\
\hline kényszerből elfogadja & - & 9,4 \\
\hline nem & 57 & 31,3 \\
\hline igen & 64,0 & 54,8 \\
\hline országon kívülről érkezök & 4,0 & 6,5 \\
\hline igen, de feltételekhez köti & 32,0 & 38,7 \\
\hline nem &
\end{tabular}

Forrás: Saját kutatás, 2017.

A gyakorisági adatok alapján (4. táblázat) az tapasztalható, hogy azok, akik úgy érzik kényszerből elfogadják az országon belülről érkezőket utcájukba, vagy szomszédjukba, 6 személyböl 5-en a régi soproniak csoportjába tartoztak és körükben viszonylag magasabb volt azok arány, akik bár elfogadják az országon belülről érkezőket, de csak bizonyos feltételekkel (43,8\%, 14 fö)). Ennek aránya az új soproniak körében 38,5\% (10 fó) volt. Ennek megfelelöen a régi soproniak kisebb aránya mutatott egyértelmüen elfogadó attitüdöt, azaz adott igen választ (31,3\%, 10 fö), ez az új soproniaknál 57,7\% (15 fö) volt. Az országon kívülröl érkezők esetében ilyen eltérést a két csoport között nem tapasztaltam a gyakorisági adatok vizsgálata alapján.

\section{A „soproni” jelentése és „soproniság” megitélése régi és új soproniak körében}

A válaszok kódolását és kategorizálását követően elsőként a „Mit jelent Önnek az, hogy „soproni” kérdésre adott válaszokat vizsgáltam. Összességében a teljes mintán a leggyakoribb válaszok az otthonának tekinti $(28,3 \%, 17$ fó), az itt született $(21,7 \%, 13$ fó) és az itt él (16,7\%, 10 fö) válaszok voltak. A három leggyakoribb választ vizsgálva az új és régi soproniak jelentős eltérést nem mutattak. A gyakorisági adatokat alapján azt tapasztaltam, hogy a régi soproniak viszonylag nagyobb aránya tekinti otthonának Sopront, így a soproni jelentését is az otthonhoz kapcsolja (32,4\%, 11 fó), ennek aránya az új soproniak körében 23,1\% (6 fö) volt. Ennek megfelelőn azok, akik a soproni jelentését a város szeretetével írták le, szintén többségében régi soproniak voltak. Érdemes megfigyelni, hogy a köznyelvben is jelenlévő hüség és hüség városa, valamint a büszkeség kifejezéseket csak a régi soproniak adták meg.

A másik kérdésem arra vonatkozott, hogy mi a véleményük „Miben nyilvánul meg a „soproniság”?”. Erre a kérdésre adott válaszok szinte a kódolás és kategórizálást követően közel azonosak voltak a soproni jelentése kérdésre adott válaszokkal. Összességében a teljes mintát nézve a „soproniság” megnyilvánulásának leggyakoribb válasza a sajátos kultúra és 
szellemiség (26,7\%, 16 fö) volt. Fontos megjegyezni, hogy ezt elsősorban a régi soproniak említették, közülük 15-en adták ezt a választ, ez a régi soproniak $25 \%$-át jelentette, míg az új soproniak közül csupán 1 fő adta ezt a választ. A „soproniság” megítélésére adott válaszok rendkívül heterogének voltak, a gyakorisági adatok alapján a fentieken kívül megfigyelhető még, hogy az új soproniak „leggyakoribb” válasza a nincs különösebb jelentése volt, ezt 7 személy adta (26,9\%). Összességében eredményeim alapján úgy tünik, hogy a személyek nehezebben adtak választ erre a kérdésre a „soproni” jelentéséhez képest, sokan a korábbi válaszukat ismételték meg, nem téve különbséget a soproni jelentése és soproniság megítélése között. Mindkét esetben viszonylag magas volt a nem adekvát, így nem kódolható/kategorizálható válaszok aránya.

\section{Sopron elhagyásának okai régi és új soproniak körében}

Végül azt vizsgáltam, hogy milyen okokat jelöltek meg a régi és új soproniak azzal kapcsolatban, ha elköltöznének a városból. Összességében a leggyakoribb okok között említették a sajátos kultúrát és szellemiséget (31,7\%, 19 fö), ami azért érdekes, mert a „soproniság” megítélésére adott válaszok között ez mutatta a legnagyobb gyakoriságot. Nagyszámba jelöltek meg olyan egyéb okokat, mint munka, tanulás, pár elköltözése stb. (35\%, 21 fö), illetve az új környezetbe, családi házba költözés (11,7\%, 7 fö). Ugyanakkor egynegyedük (25\%, 15 fö) nem költözne el. További 6 fő (10\%) adta meg a lokálpatriotizmust, mint okot Sopron elhagyására. Egyértelműen, mint várható volt a régi soproniak szignifikánsan $\left(\chi^{2}(1)=7.330, p=0.008\right)$ nagyobb aránya jelezte, hogy nem költözne el $(21,7 \%, 13$ fó), az új soproniakhoz képest $(3,3 \%, 2$ fó). Ennek megfelelöen a új soproniak tendenciaszerün szignifikáns mértékben $\left(\chi^{2}(1)=4.538, p=0.055\right)$ nagyobb aránya adott meg egyéb okokat Sopron elhagyására $(21.7 \%, 13$ fö), mint a régi soproniak (13,3\%, 8 fö).

\section{Következtetések}

A tanulmányban bemutatott folyamatok elsősorban pillanatfelvételül szolgálnak, zajló folyamatok regisztrálásaként. Álláspontom szerint, a térszerkezeti átalakulásokkal összefüggésben jelentkező migrációs folyamatok, a gazdaságszerkezet változásai, olyan regionális változásokhoz vezetnek, melyek a globális térbe integrált régióknak addigi zárt társadalmat is nyitásra, de legalábbis válaszreakcióra késztetik. A nemzeti vagy uniós szinten meghozott döntések legtöbbször nem képesek megjeleníteni azokat a regionális sajátosságokat, melyek a régió korábbi térfelhasználásának megváltozásából fakadnak. Az e munkában vázolt folyamatok regionális, nyitott térben jelen lévő felek (vállalkozások, helyi vagy migrációval érkező munkavállalók) kölcsönös egymásra hatásából fakadó lokális válaszmintázatok. A megváltozott, integrálódó és egyre átjárhatóbb térszerkezetben elsősorban nem a központi, országos közigazgatási szabályozásnak, hanem a megváltozott regionális sajátosságokat szem előtt tartó, országok közötti szabályozási együttműködésre van szükség az érintett régiók fejlődésének előmozdítása érdekében. Ennek a megfontolásnak lehet érvényes üzenete a politikai döntéshozatal számára is.

A kismintás kérdőíves vizsgálat eredményei jelzésértéküek és rávilágítottak a határmenti városok migrációval kapcsolatos vizsgálatoknak a fontosságára. A vizsgálat alátámasztotta, hogy az új lakókban még nem alakult ki az a lokálpatriotizmus, ami miatt minden áron lakhelyükön maradnának. A legfőbb lakóhelyváltási ok az új munkalehetőség, valamint a család közelsége mind a régi és az új soproniak számára egyaránt. A migráció kifejezés értelmezésével kapcsolatban az tapasztalható, hogy a régi soproniak több negatív tartalmú véleményt fogalmaztak meg az új soproniakhoz képest. Határmenti települési voltából is adódóan a migráció jelenségével a válaszadók közel egyharmada már 15 - 20 éve találkozott, 
de sokan csak az elmúlt évek menekült helyzete révén szembesült vele. Az országon belüli lakhelyváltoztatást a jobb munkalehetőség reményében a megkérdezetteknek valamivel több mint a fele tekinti migrációnak. A betelepülési támogatást a válaszadók többsége csak a külföldi menekültek esetében tartja indokoltnak. A válaszadókat jellemzően elfogadó attitűd jellemzi az országon belülről és kívülről érkezők betelepülőkkel kapcsolatban. Az új és a régi soproniak válaszait tekintve nem volt szignifikáns különbség a „soproni” és a „soproniság” fogalmakhoz társított tartalmak között. Számukra az otthont jelenti, mely sajátos kultúrával és szellemiséggel jellemezhetö.

\section{Irodalomjegyzék}

1. Deák M. (2015): Sopron és Ebenfurth közötti kétvágányúsítás területfejlesztési hatásai. Nyugati-dunántúli regionális fejlesztési ügynökség összeállítása. Nyugatdunántúli Regionális Fejlesztési Ügynökség, Szombathely. http://westpa.hu/download/files/525

2. Fóti K. (2003): Potential migration from Hungary to Austria after EU accession and possible impacts of this. MTA Világgazdasági Kutatóintézet, Budapest. 25 p.

3. Gödri I. (2010): Migráció a kapcsolatok hálójában. A kapcsolati tőke és a kapcsolathálók jelenléte és szerepe az ezredvégi magyarországi bevándorlásban. KSH NKI Kutatási Jelentések 89. KSH Népességtudományi Kutató Intézet, Budapest. 211 p. ISBN 978-963-235-276-3

4. Hardi T. (2005): Határon átnyúló ingázás, munkavállalás az osztrák-magyar határtérségben, in: Tér és Társadalom, Vol. 19(2), 65-81 p. ISSN 0237-7683

5. Határátkelő blog (2019): Mit dolgoznak a magyarok Ausztriában. https://hataratkelo.blog.hu/2019/09/10/mit_dolgoznak_a_magyarok_ausztriaban

6. Hárs Á. - Simon D. (2015): A munkaerő-migráció változása kétezres években Magyarországon. Vizsgálat a munkaerő-felmérés adatai alapján. MTA Közgazdaságés Regionális Tudományi Kutatóközpont Közgazdaságtudományi Intézet - Budapesti Corvinus Egyetem Emberi Erőforrások Tanszék, Budapest. 108 p. ISBN 978-6155447-75-4

7. Hárs Á. (2011): Magyarok külföldi munkavállalása. Kopint-Tárki Zrt., Budapest. http://nfsz.munka.hu/resource.aspx?resourceid=ak_euegt_eloadasok_magyarok_kulf oldon

8. Hidas Zs. - Kezán A. - Némethné Csehi T. (2012): Magyarország társadalmi atlasza, in: Vida J. (szerk.): KSH időszaki kiadvány. KSH, Budapest. https://www.ksh.hu/docs/hun/xftp/idoszaki/pdf/tarsatlasz.pdf

9. HRportál (2019): Rekordot döntött az Ausztriában dolgozó magyarok száma. https://www.hrportal.hu/hr/rekordot-dontott-az-ausztriaban-dolgozo-magyarokszama-20190321.html

10. Kincses Á. (2014): Nemzetközi migrációs körkép Magyarországról a 2011-es népszámlálási adatok alapján, in: Területi Statisztika, Vol. 54(6), 590-605 p. ISSN 0018-7828

11. Kincses Á. (2015): A szomszédos országok migrációs forrásterületeinek a vizsgálata a magyar népszámlálási adatok felhasználásával 2001 és 2011 között, in: Területi Statisztika, Vol. 55(5), 407-431 p. ISSN 0018-7828

12. KSH [Központi Statisztikai Hivatal] (2013): 2011-es népszámlálás - 3. területi adatok 3.8. Győr-Moson-Sopron megye Központi Statisztikai Hivatal, Győr. http://www.ksh.hu/nepszamlalas/teruleti_adatok 
13. L. Rédei M. (2013): Átalakuló társadalom - új folyamatok és következmények a megyékben, in: XIX. Országos Urbanisztikai Konferencia. 2013.04.17-19. Mosonmagyaróvár. http://www.mut.hu/?module=news\&action=getfile\&fid=196526.

14. L. Rédei M. (2014): A nemzetközi migráció demográfiai és geográfiai aspektusai, in: Tarrósy I. - Glied V. - Vörös Z. (szerk.): Migrációs tendenciák napjainkban. IDResearch Kft. - Publikon Kiadó, Pécs, 29-45 p.

15. Lakatos J. (2015): Külföldön dolgozó magyarok, Magyarországon dolgozó külföldiek, in: Statisztikai Szemle, Vol. 93(2), 93-112 p. ISSN 0039-0690

16. Nyitrai J (szerk.) (2012): Burgenland és Nyugat-Dunántúl - a határ két oldala. KSH időszaki kiadvány. http://www.ksh.hu/docs/hun/xftp/idoszaki/regiok/gyorburgenland.pdf

17. Portes A. - Sensenbrenner, J. (2001): Keserü kenyér: a munkaerő nemzetközi migrációjának szociológiai problémái, in: Sik E. (szerk.): A migráció szociológiája. Szociális és Családügyi Minisztérium, Budapest, 69-85 p.

18. Projactive Consulting Kft. (2018): AZ OSZTRÁK-MAGYAR HATÁRMENTI INGÁZÓI FOLYAMATOK, ÉS AZ ÖKET TÁMOGATÓ SZERVEZETI HÁTTÉR VIZSGÁLATA, ELEMZÉSE. Kutatási jelentés. https://www.interregathu.eu/fileadmin/be_user_uploads/Fairwork/Downloads/Vegleges_kutatasi_jelentes 2018.01.pdf

19. Rechnitzer J. - Páthy Á. - Berkes J. (2014): A magyar városhálózat stabilitása és változása, in: Tér és Társadalom, Vol. 28(2), 105-127 p. ISSN 0237-7683

20. Rechnitzer J. (2001): Szerkezeti változások a regionális gazdaságban. PTE Közgazdaságtudományi Kar, Regionális Politika és Gazdaságtan Iskola, Pécs (Habilitációs előadások 2.). ISBN 9636418454

21. Rechnitzer J. (2014): A győri jármüipari körzetről szóló kutatási program, in: Tér és Társadalom, Vol. 28(2), 3-10 p. ISSN 0237-7683

22. Rédei M. - Jakobi Á. - Jeney L. (2002): Regionális specializáció és a feldolgozóipari tevékenység változása, in: Tér és Társadalom, Vol. 16(4), 87-108 p. ISSN 0237-7683

23. Sik E. (1999): Magyarok az osztrák munkaerőpiacon, in: Sik E - Tóth, J. (szerk.): Átmenetek. MTA Politikai Tudományok Intézete, Budapest, 123-172 p.

24. Szabó M. (1999): A Lajta bánság fantomja, in: Beszélö, Vol. (4)6. http://beszelo.c3.hu/cikkek/a-lajta-bansag-fantomja

25. Uniós migráció Ausztriába - trendek és irányok (2016): http://medienservicestelle.at/migration_bewegt/2016/05/09/eu-migration-nachoesterreich-entwicklungen-und-trends/

26. Valuch T. (2014): A magyar társadalom a rendszerváltás után, in: A Történelemtanárok Egylete által szervett Közelmúltunk jelene. Magyarország története, 1989-2014. című konferencián elhangzott előadás bővített, írásos változata. http://www.tte.hu/media/konf2014/TTE_2014_ValuchTibor.pdf 